\title{
Design of Cow-Dung and Grass- Clippings Isothermal Continuous Stirred Co-digester for biogas production
}

\author{
Abowei M.F.N, Akinwande A.C and Akpa J.G \\ Department of Chemical/Petrochemical Engineering \\ Rivers State University \\ Port Harcourt, Nigeria.
}

\begin{abstract}
The continuous search in renewable energy sources for industrial and domestic utilization is very imperative and motivated this study. The study of Cow-dung and grass clippings Co-digestion are important due to the fact that the successful outcome of the studies will provide a basis for waste minimization and enhance renewable energy production for global consumption. This work, therefore, is focused by exploiting the modified Gompertz kinetic equation in developing design models for the simulation of continuously stirred co-digester (CSC) at the isothermal condition. Co-digester functional dimensions such as volume, length, space-time, space velocity and heat generation per unit volume were developed for Continuous Stirred Co-digester type..The developed models were simulated using Matlab codes programming technique using the design basis of 50,000 metric tons of biogas per annum at $370 \mathrm{C}$ isothermal condition. The developed performance models were solved numerically using MATLAB version 7.1 within the operational limit of conversion degree, $X A=0.1$ to 0.9. The results obtained showed that the increase in fractional dimensions of Co-digester volume VR, length LR, and Spacetime SV- increases with an increase in fractional conversion at a constant radius. Results of space velocity (SV-) and heat generation/per unit volume (q) showed inverse characteristic behavior as an increase in fractional conversion decreases space velocity and heat generation per unit volumes.. Further careful examination of the results, demonstrated that at an optimal yield of 0.9 degrees of conversion, Co-digester volume value of $10.0 \mathrm{~m} 3$ at constant radius was feasible. The results as obtained in this work proved a dependable relationship with the fractional conversion.
\end{abstract}

Key Words: Design, Isothermal, Grass-clipping, Cow-dung Continuous Stirred, Co-digester, Gompertz rate Equation.

\section{INTRODUCTION}

Researchers globally have resolved in tackling the high potential of global warming problems resulting from the utilization of non-renewable energy sources for industrial and domestic use. These have led to increased awareness search (Angelidaki, 1996; Angelidaki et al, 2003; Igoni et al, 2008; Abdulsalam \& Yusuf, 2015; Igoni \& Harry, 2017) for alternative renewable energy sources, such as biogas and bio-fuels production; that expected to elevate global economy and minimize global warming problems. In addition, the significance of this study will also encompass the following; (Angelidaki 1996). It will reduce the environmental nuisance of cow-dung and grass clippings waste contamination problems (Abowei \& Goodhead 2014). The $\mathrm{CH}_{4}$ gas produced will be useful for both industrial and domestic application (Igoni et al 2008). The digester models to be developed in this work will be generalized and can be applied with a known kinetic model to simulate the functional dimensions of any digester type.

To this end, it is necessary to research on the possibilities of developing various Co-digester types in the treatment and production of bio-gas using all domestic and industrial wastes routes. Major expected achievable deliverables in this waste recycling process are waste minimization, renewable product formation, boost global economy and of course enhances employment capacity. Hence, this research is a prelude to the adoption of modified Gompertz rate equation sighted in (Anthony et al, 2015) works of Cow-Dung and Grass Clipping combination as raw materials for renewable energy sources.

In order to establish the design models with respect to the Isothermal continuous stirred co-digester unit, it is relevant to appraise quantitatively and qualitatively the scientific aspect of cow-dung and grass-clippings as related to properties, structure, and reaction mechanisms. Interestingly, cow-dung and grass-clippings are readily available materials that can be used to produce biogas through the biodegradability in a co-digester process. 


\subsection{Cow-Dung Properties and Structure}

Colour: black

Density $=22 \mathrm{~kg} / \mathrm{m}^{3}$

The chemical structure of Cow dung is mainly the combination of Ammonium carbonate hydroxide and cellulose and small proportion of Phosphate, Potassium and calcium. Thus;

$\left(\mathrm{NH}_{4}\right)_{2} \mathrm{CO}_{3} \mathrm{OH}+$

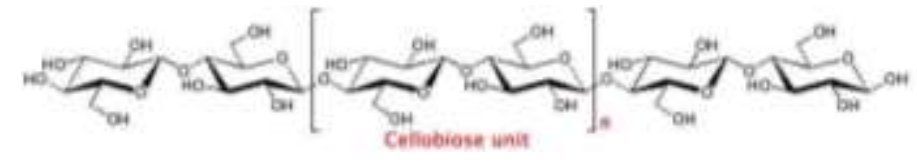

$$
\Rightarrow \text { Cow Dung }
$$

Ammonium Carbonate Hydroxide

Grass-Clippings Properties and Structure
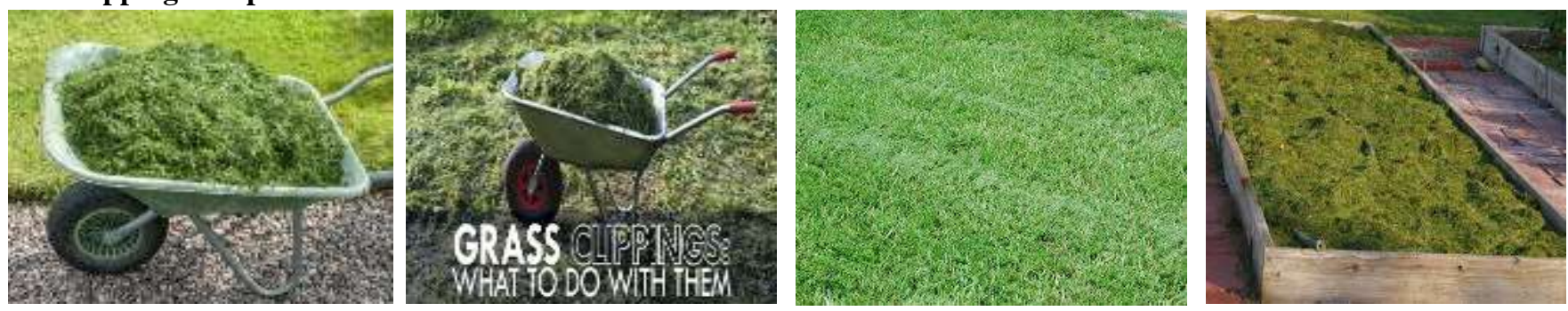

Typical Grass Clipping processes

The following physical characteristics are identified with grass clipping;

Colour: Green

Density =

$$
\begin{aligned}
& 91-227.445 \mathrm{~kg} / \mathrm{m}^{3} \text { (Garden Grass) } \\
& 150-450 \text { for Garden Trees }
\end{aligned}
$$

\section{Structure of Grass Clipping}

1. a-D-Glucose

2. Starch

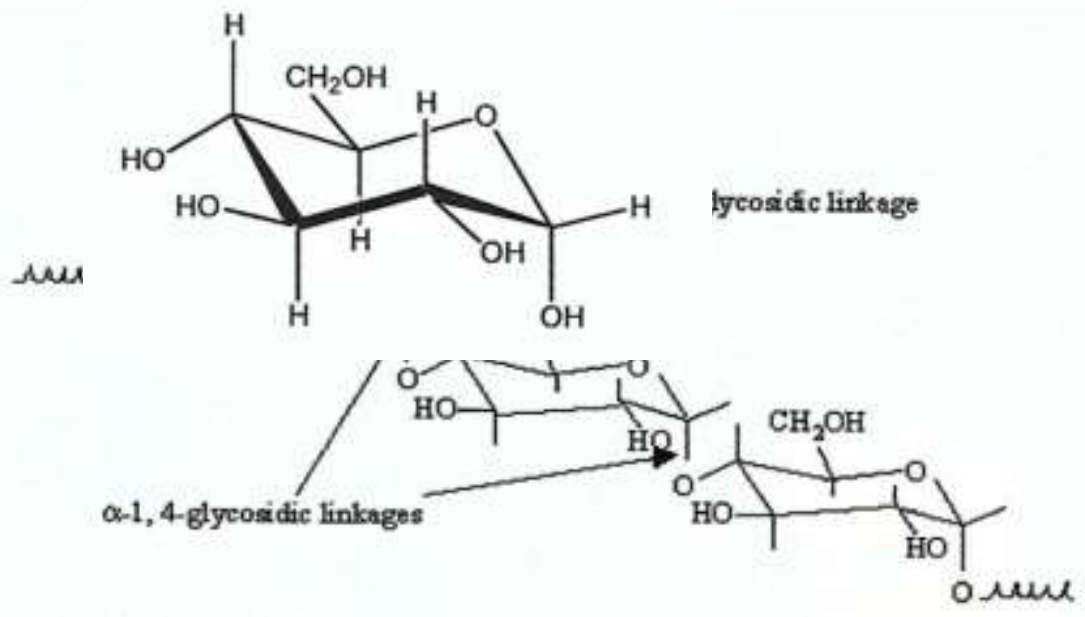


3.

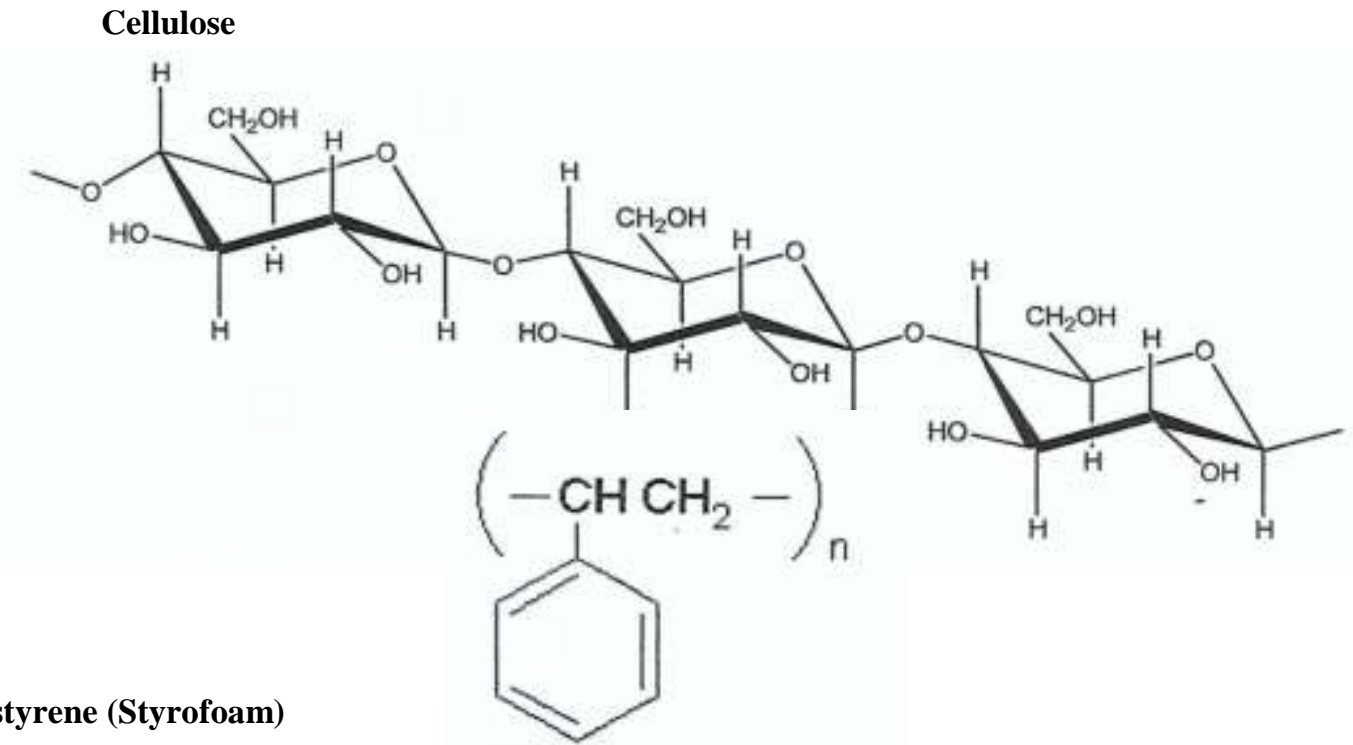

\section{4.Polystyrene (Styrofoam)}

\section{Properties and structure of Biogas $\left(\mathrm{CH}_{4}\right)$}

It physical properties includes;

$\begin{array}{ll}\text { Density } \quad= & 1.5 \mathrm{~kg} / \mathrm{m}^{2} \\ \text { Viscosity } & =\quad 1.13 \mathrm{~kg} / \mathrm{s} . \mathrm{m} \\ \text { Moisture Content }= & 50-70 \%\end{array}$

\section{Stoichiometry of Grass Clippings and Cow-Dung Reaction}

The possible stoichiometric equation describing grass clipping cow-dung reaction is invoked using induction principles of reaction mechanism and proposed as;

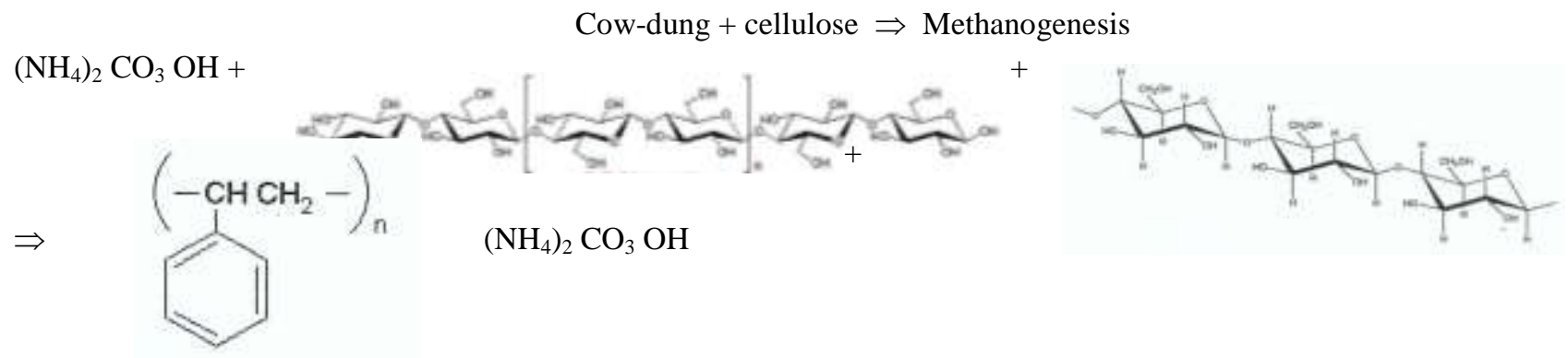

\subsection{KINETIC RATE ANALYSIS}

Numerous kinetic rate analysis were been postulated regarding bio-gas production from various municipal and industrial waste types. Matheri et al., (2017) worked on optimizing biogas production from anaerobic co-digestion of chicken manure and organic fraction of municipal solid waste. In this work, the use of biochemical methane potential with 4:1 ratio with optimal biodegradation rates gave optimum biogas (methane) yield with 15 days retention time. Since it was an experimental research work, the materials were sourced locally and then subjected to laboratory investigation for results and discussions. The methanogenesis of the process gave $\mathrm{CO}_{2}$ and biogas $\left(\mathrm{CH}_{4}\right)$ i.e. Glucose $\longrightarrow \mathrm{CO}_{2}+$ methane.

Their findings gave reasonable amount of moisture content at $37^{\circ} \mathrm{C}$ and $\mathrm{pH} 7$ which after Buswell formula was used to determine the percentage of methane gave $40-70 \%\left(\mathrm{CH}_{4}\right)$ and $30-60 \%\left(\mathrm{CO}_{2}\right)$ and other traces of other elements. Thus, their work gave optimum biogas and methane yield at ratio of $1: 1$ but optimum biogdegradability is at $4: 1$ ratio.

Abdulsalam and Yusuf (2015) investigated the kinetic of biogas produced from cow and elephant dungs using residual substrate concentration approach. In the batch bio-digester, anaerobically the best biogas production of $3.92 \times 10^{-4} \mathrm{~g} / \mathrm{cm}^{3}$ and average yield of 0.0845 over a period of 33 days follow a kinetic shifting order of $(0-1)$. Also, the co-digestion of elephant and cow-dung of equal proportion can increase the yield of biogas.

Sreekrishnan (2004) researched on the design models for Anaerobic Batch Digesters producing Biogas from municipal solid waste. The use of Microsoft Visual Basic version 6.0 computer programme with fractional conversion range of $0.2 \leq \alpha \leq 0.8$ to get empirical optimum yield of $20 \%$ in the batch digester. A lot of literatures reviews were carried out on waste management in 
Port Harcourt. Their materials were 5 batch-wise anaerobic digester of 5 litres for the experimental set-up. The digesters were the loaded with $2 \mathrm{~kg}$ of organic municipal solid waste which was diluted to $26.7 \%$ total solids concentration and end up with the usual Monod rate equation.In addition, other researchers also limited their works to the laboratory analysis of possible methane production resulting to the use of Monod rate equation (Lastella et al 2002; Latinwo \& Agarry 2015; Matheri 2015, 2016 \& 2017) $\mu=\mu_{\max } \frac{[S]}{K_{s}+[S]}$

Where;

$\mu_{\max }=\quad$ Maximum growth rate, day $^{-1}$

$[\mathrm{S}]=$ Concentration of limiting substrate, $\mathrm{mg} / \mathrm{L}$

$\mathrm{K}_{\mathrm{s}}=$ Half-saturation constant (i.e. concentration of $\mathrm{S}$ when $\mu=\frac{\mu_{\max }}{2}$ ),

$\mathrm{mg} / \mathrm{L}$

$\mu_{n e t}=\mu_{\max } \frac{[S]}{K_{s}+[S]}[X]-k_{d}[X]$

Where;

$\mathrm{k}_{\mathrm{d}} \quad=\quad$ Decay constant, day $^{-1}$

\subsection{Modified Gompertz Kinetic Expression}

Interestingly, Etuwe, C.N., et al (2016) worked on the development of mathematical models and application of the modified Gompertz model for Designing Batch Biogas Reactors. They got yield optimal $\left(\mathrm{y}_{\mathrm{t}}\right)$ of $60-80 \mathrm{~g}$. VS/L at 42 days period. Comparatively, the modified Gompertz formula gave minimum time $(\lambda)$ of $9.7-12$ days and maximum yield ( $\mathrm{y}_{\mathrm{m}}$ ) of 68 and $86 \mathrm{ml} / \mathrm{g}$ at operating temperature of $37^{\circ} \mathrm{C}$ and $\mathrm{pH}$ of 7.

Further work was reported on the kinetic of biogas rate from cow dung and grass clippings resulting to biogas production on a laboratory scale level.(Matheri etal 2015; Anthony et al 2015). Their works resulted in the development of a concise modified rate expression as follows:

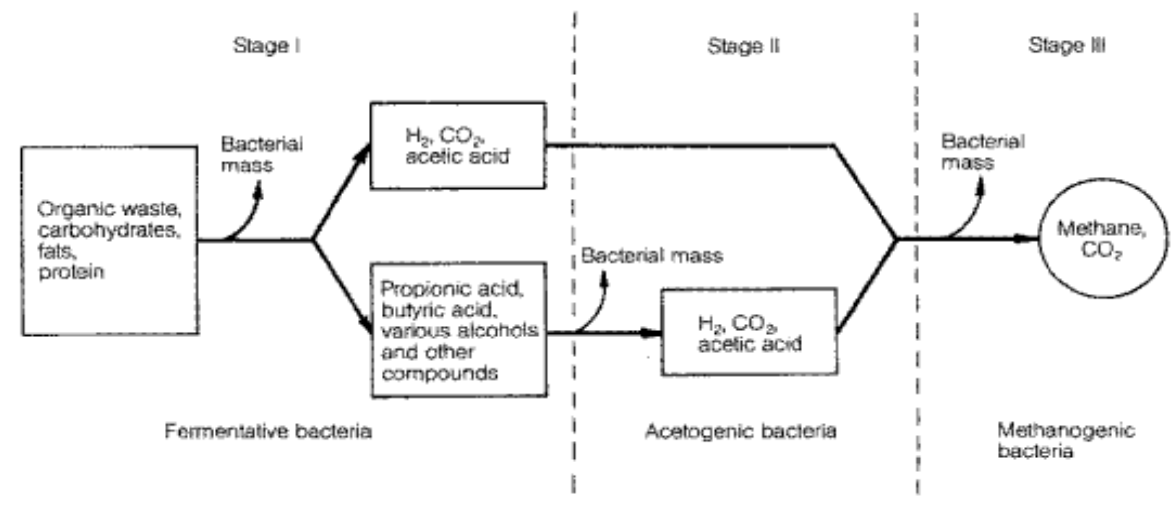

Fig. 1 Hypothetical Methanogenic process

Gompertz (Pesta 2007; Ostream 2004; Anthony 2015; Etuwe et al 2016) Considered a Pseudo - first order reaction process for the decomposition of cow-dung to $\mathrm{CO}_{2}$ and $\mathrm{CH}_{4}$ for the methonogenic bacteria process as shown below:

$\mathrm{C}_{6} \mathrm{H}_{12} \mathrm{O}_{6_{(L)}} \stackrel{\mathrm{K}}{\longrightarrow} 3 \mathrm{CO}_{2_{(g)}}+3 \mathrm{CH}_{4_{(g)}}$

The rate expression for the methanogenesis process gives;

$\left.\begin{array}{l}\left(-r_{A}\right) \alpha C_{A}^{n} \\ \left(-r_{A}\right)=K C_{A}^{n}\end{array}\right\}$

Since it is a Pseudo - first order reaction, $\mathrm{n}=1$ hence, equation (50) becomes;

$\left(-r_{A}\right)=\frac{-d C_{A}}{d t}=K C_{A}$ 
In terms of fractional conversion, $\mathrm{X}_{\mathrm{A}}$

$\left(-r_{A}\right)=k C_{A o}\left(1-X_{A}\right)$

Where;

$\mathrm{k} \quad=\quad$ Rate constant which is a function of time and it represent pre-exponential factor (A) in the modified Gompertz equation as;

$\left(-r_{A}\right)=\quad$ Depleting rate of reactant and it is represented in the modified Gompertz equation as $Y(t)$

$\left(-r_{A}\right)=Y(t)=A \exp \left[-\exp \left(\frac{\mu e}{A}(\lambda-t)+1\right)\right] C_{A o}\left(1-X_{A}\right)$

Equation (53) represent the rate law used for bio-gas production which will be exploited for the design of the continuous stirred co-digester.

Where;

$\begin{array}{lll}\mathrm{A} & = & \text { Biogas production potential } \\ \mathrm{Y} & = & \mathrm{k}(\mathrm{t})=\text { cumulative of specific biogas production } \\ \mu & = & \text { Maximum biogas production rate }\left(\mathrm{d}^{-1}\right) \\ e & = & \text { Mathematical constant }(2.718282) \\ \mathrm{t} & = & \text { Cumulative time for biogas production (days) } \\ \lambda & = & \text { Lag-phase period } \\ \mathrm{C}_{\mathrm{AO}} & = & \text { Initial concentration of the glucose; } \mathrm{mol} / \mathrm{L} \\ \mathrm{X}_{\mathrm{A}} & = & \text { Fractional conversion of converted reactant to product }\end{array}$

Since the works reviewed used batch wise laboratory scale method to establish the Gompertz rate equation, it is worthwhile to adopt the modified rate equation to establish large scale design for various co-digester types. Therefore this work is focused on the application of Gompertz modified rate equation to design a Isothermal Continuous Stirred Co-digester (CSC) for bio-gas production using cow-dung and grass-clipping as raw materials.

\subsection{MATERIALS AND METHODS}

\subsection{Materials}

The materials exploited in this work encompassed mainly desk top research component such as; Laptop, Mathlab software, work spreadsheet and other associated computational tools for the simulation of the developed models below.

\subsection{Development of Design Models}

Applying simple material balance equation (Perry \& Green 2008) is utilized for the development of the modeling equation thus; Input $=$ output + Rate of disappearance + Accumulation. In this work consideration is based on the fact that flow is in steady state at isothermal condition with inform stirring and negligible pressure drop within the within the co-digester system, then;

\subsection{Co-Digester Volume Model}

Consider the schematic representation of a hypothetical continuous stirred co-digester with feeds and product as shown below.

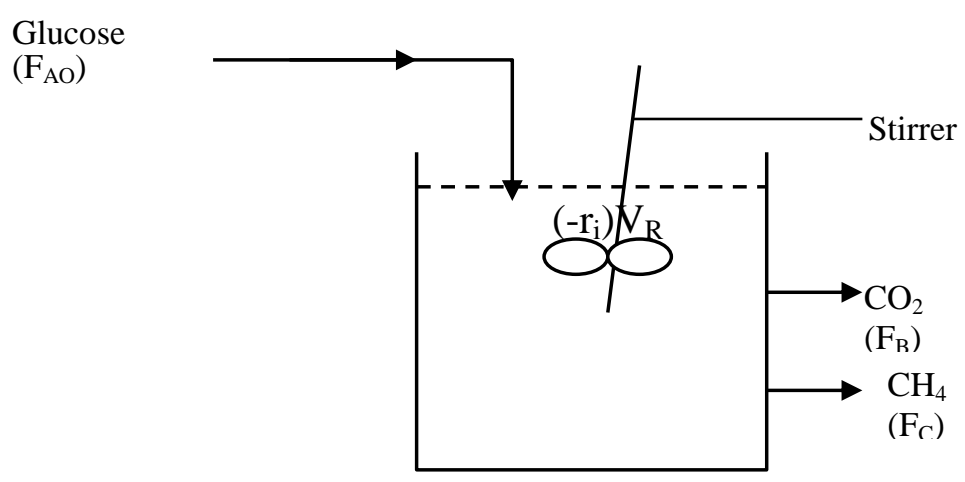

Figure 2: Hypothetical Continuous Stirred Co-digester 
$\left.\begin{array}{lll}\text { Input } & = & F_{A}=F_{A O}\left(1-X_{A o}\right)=F_{A O} \\ \text { Output } & = & F_{A f}=F_{A O}\left(1-X_{A}\right)=F_{A O}-F_{A O} X_{A} \\ \text { Rate of disappearance }= & -r_{A} V_{R}\end{array}\right\}$

Accumulation $\quad=\quad \frac{d}{d t}\left(C_{A} V_{R}\right)=0$

Combining equation (8) to (9) yields

$\frac{d}{d t}\left(C_{A} V_{R}\right)=F_{A O}-\left[F_{A O}\left(1-X_{A}\right)\right]-\left(-r_{A}\right) V_{R}$

At steady state, the accumulation term is equal to zero, i.e.

$$
\begin{aligned}
& \frac{d}{d t}\left(C_{A} V_{R}\right)=0 \\
& \therefore \quad 0=F_{A O}-\left[F_{A O}\left(1-X_{A}\right)\right]-\left(-r_{A}\right) V_{R}
\end{aligned}
$$

Expanding the bracket and simplifying;

$0=F_{A O}-F_{A O}+F_{A O} X_{A}-\left(-r_{A}\right) V_{R}$

$0=F_{A O} X_{A}-\left(-r_{A}\right) V_{R}$

$V_{R}=\frac{F_{A O} X_{A}}{\left(-r_{A}\right)}$

Substituting equation (12) into equation (7) yields the generalized model, thus;

$V_{R}=\frac{F_{A O} X_{A}}{A \exp \left[-\exp \left(\frac{\mu e}{A}(\lambda-t)+1\right)\right] C_{A o}\left(1-X_{A}\right)}$

\section{Co-digester Length $\left(\mathbf{L}_{\mathbf{R}}\right)$ Model}

Since the reactor is cylindrical, volume of a cylindrical reactor is given as

$V_{R}=\pi R^{2} L_{R}$

Where:

$\mathrm{V}_{\mathrm{R}} \quad=\quad$ Volume of reactor $\left(\mathrm{m}^{3}\right)$

$\mathrm{R}=\quad$ Radius of reactor $(\mathrm{m})$

$\mathrm{L}_{\mathrm{R}} \quad=\quad$ Length of reactor $(\mathrm{m})$

$\pi=$ Constant

Comparing equations (13) into (14) yields,

$L_{R}=\left[\frac{F_{A O} X_{A}}{2 \pi r^{2} \cdot A \exp \left[-\exp \left(\frac{\mu e}{A}(\lambda-t)+1\right)\right] C_{A o}\left(1-X_{A}\right)}\right]^{1 / 3}$

\section{Co-digester Space Time $\left(\tau_{\mathrm{CSTR}}\right)$ Model}

This is defined as the ratio of reactor volume to volumetric flow rate. thus 
$\tau_{C S T R}=\frac{V_{R}}{v_{O}}$

Substituting equation (13) into (16) yields

$\tau_{C S T R}=\frac{\frac{F_{A O} X_{A}}{A \exp \left[-\exp \left(\frac{\mu e}{A}(\lambda-t)+1\right)\right] C_{A o}\left(1-X_{A}\right)}}{v_{O}}$

$F_{A O}=C_{A O} v_{O}$

Substituting equation (18) into (17) yields,

$$
\tau_{C S T R}=\frac{X_{A}}{A \exp \left[-\exp \left(\frac{\mu e}{A}(\lambda-t)+1\right)\right] C_{A o}\left(1-X_{A}\right)}
$$

\section{Co-digester Space Velocity $\left(\mathbf{S}_{\mathbf{V}}\right)$}

This is defined as the reciprocal of space time and mathematically modeled as.

$$
S_{V}=\frac{1}{\tau_{C S T R}}
$$

Substituting equation (19) into (20) yields

$$
S_{V}=\frac{A \exp \left[-\exp \left(\frac{\mu e}{A}(\lambda-t)+1\right)\right] C_{A o}\left(1-X_{A}\right)}{X_{A}}
$$

\section{Co-digester Heat Generated Per Unit Volume}

Exploiting the works Abowei and Goodhead (2014), heat generation per unit volume model is derived as;

$$
Q=\Delta H_{R} F_{A O} X_{A}
$$

$\mathrm{Q}=\mathrm{Quantity}$ of Heat $(\mathrm{j} / \mathrm{s})$

$\Delta H_{R}=$ Heat of reaction $(\mathrm{KJ} / \mathrm{mol})$

$F_{A O}=$ Flow Rate of Species $(\mathrm{mol} / \mathrm{s})$

$X_{A}=$ Fractional Conversion of Species

Dividing through by $\mathrm{V}_{\mathrm{R}}$

$$
\begin{aligned}
& \frac{Q}{V_{R}}=q=\frac{\Delta H_{R} F_{A O} X_{i}}{V_{R}} \\
& q=\frac{\Delta H_{R} F_{A O} X_{A}}{V_{R}}
\end{aligned}
$$

Where $\mathrm{q}$ = quantity of heat generated per unit volume of the co-digester Combining Equations 24 and 13 results in;

$$
q=\frac{\Delta H_{R} F_{A O} X_{A}}{F_{A O} X_{A}} \frac{\mu \exp \left[-\exp \left(\frac{\mu e}{A}(\lambda-t)+1\right)\right] C_{A o}\left(1-X_{A}\right)}{A}
$$

Equation 25 can be simplified as; 
International Journal of Advances in Scientific Research and Engineering (ijasre), Vol 5 (3), March-2019

$q=\frac{\Delta H_{R}}{\left(A \exp \left[-\exp \left(\frac{\mu e}{A}(\lambda-t)+1\right)\right] C_{A o}\left(1-X_{A}\right)\right)^{-1}}$

4.0 Computational Methods for Co-digester Design Parameters.

4.1 Stoichiometric mole computations

The essential operating design parameters for the simulation process were computed from the summarized stoichiometric equation. Thus;

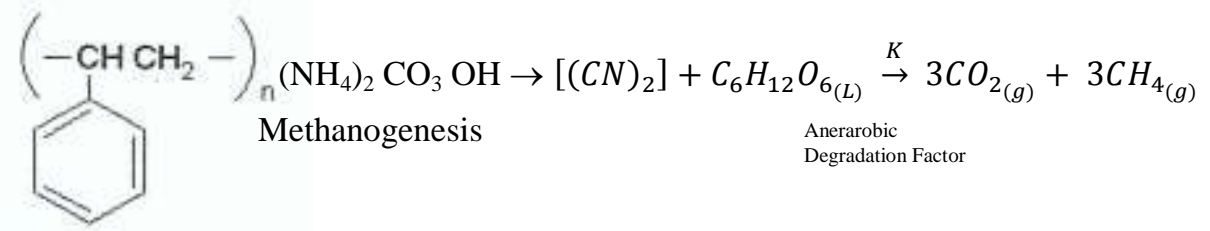

Table 1: Operating Parameters Determination.

\begin{tabular}{|c|c|c|}
\hline S/No & Parameters & References \\
\hline 1. & Rate Constant Y (t) & Anthony, et al., 2015 \\
\hline 2. & $\mathrm{C}_{\mathrm{AO}}=0.039 \mathrm{~mol} / \mathrm{m}^{3}$ & Calculated \\
\hline 3. & $\mathrm{~F}_{\mathrm{AO}}=0.00019 \mathrm{~mol} / \mathrm{s}$ & Calculated \\
\hline 4. & $\mathrm{~V}_{\mathrm{O}}=0.0047 \mathrm{~m}^{3} / \mathrm{s}$ & Calculated \\
\hline 5. & $\left(-\Delta H_{R}\right)=257 \mathrm{KJ} / \mathrm{mol}$ & Perry et al., 2008 \\
\hline 6. & Design Stress, $f=130 \mathrm{~N} / \mathrm{mm}^{2}$ & Sinnott, et al., 2009 \\
\hline 7. & Corrosion Allowance e $=1.25 \mathrm{~mm}$ & Sinnott, et al., 2009 \\
\hline 8. & Design Pressure $\mathrm{P}_{\mathrm{i}}=8.99 \mathrm{~N} / \mathrm{mm}^{2}$ & Calculated, Sinnott et al., 2009 \\
\hline 9. & Design Temperature $\mathrm{T}=150^{\circ} \mathrm{C}$ & Sinnott et al., 2009 \\
\hline
\end{tabular}


International Journal of Advances in Scientific Research and Engineering (ijasre), Vol 5 (3), March-2019

4.2 Flow Chart of Programme for CSC

\section{Start}

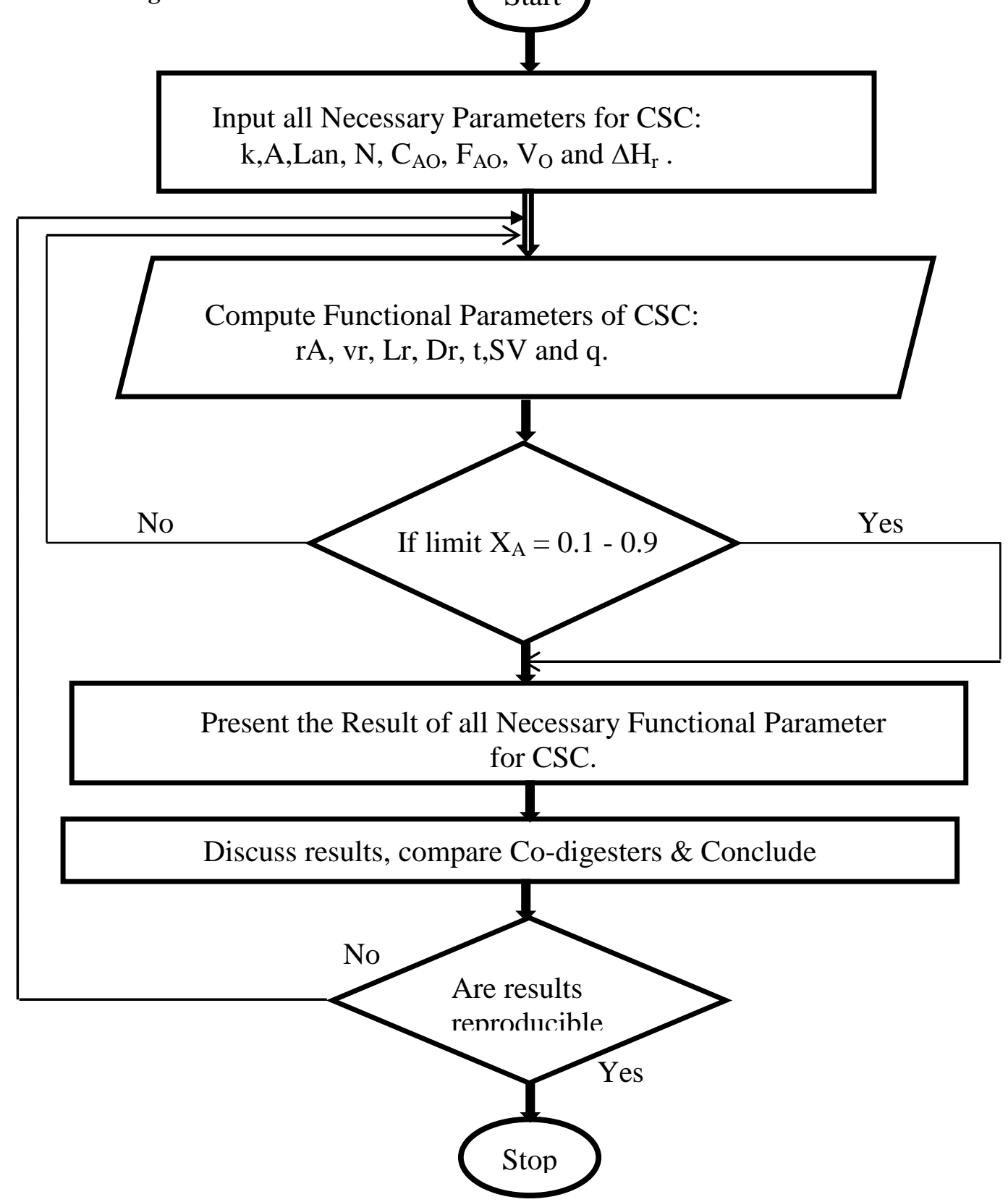

Fig. 3: Summarized Algorithm Outline Flow Chart Computational Model

\subsection{RESULTS AND DISCUSSION}

Table 2 shows the results of the Mathlab simulations to obtain functional parameters of CSTR with respect to $\mathrm{X}_{\mathrm{A}}$ (fractional conversion).

\begin{tabular}{rllllllr}
\hline \multicolumn{1}{c}{$\boldsymbol{X}_{\boldsymbol{A}}$} & $(-\boldsymbol{r})_{\boldsymbol{A}}$ & \multicolumn{1}{c}{$\boldsymbol{V}_{\boldsymbol{C S T R}}$} & \multicolumn{1}{c}{$\boldsymbol{D}_{\boldsymbol{C S T R}}$} & \multicolumn{1}{c}{$\boldsymbol{L}_{\boldsymbol{C S T R}}$} & $\boldsymbol{\tau}_{\boldsymbol{C S T R}}$ & $\boldsymbol{S}_{\boldsymbol{C S T R}}$ & $\boldsymbol{q}_{\boldsymbol{C S T R}}$ \\
\hline $\mathbf{0 . 1}$ & 0.153387 & 0.12387 & 0.428808 & 0.857616 & 0.263553 & 3.79431 & 3.834675 \\
$\mathbf{0 . 2}$ & 0.136344 & 0.278707 & 0.561898 & 1.123795 & 0.592993 & 1.68636 & 3.4086 \\
$\mathbf{0 . 3}$ & 0.119301 & 0.477783 & 0.672489 & 1.344977 & 1.01656 & 0.98371 & 2.982525 \\
$\mathbf{0 . 4}$ & 0.102258 & 0.743218 & 0.779196 & 1.558392 & 1.581315 & 0.632385 & 2.55645 \\
\hline
\end{tabular}

Table 2 Functional parameters results of CSTR with fractional conversion 
International Journal of Advances in Scientific Research and Engineering (ijasre), Vol 5 (3), March-2019

\begin{tabular}{rrrrrrrr}
\hline $\mathbf{0 . 5}$ & 0.085215 & 1.114827 & 0.891957 & 1.783913 & 2.371973 & 0.42159 & 2.130375 \\
$\mathbf{0 . 6}$ & 0.068172 & 1.672241 & 1.021036 & 2.042071 & 3.557959 & 0.28106 & 1.7043 \\
$\mathbf{0 . 7}$ & 0.051129 & 2.601263 & 1.183049 & 2.366098 & 5.534603 & 0.180681 & 1.278225 \\
$\mathbf{0 . 8}$ & 0.034086 & 4.459309 & 1.415893 & 2.831786 & 9.487891 & 0.105398 & 0.85215 \\
$\mathbf{0 . 9}$ & 0.017043 & 10.03344 & 1.855345 & 3.71069 & 21.34775 & 0.046843 & 0.426075 \\
\hline
\end{tabular}

\subsection{Effect of Fractional Conversion}

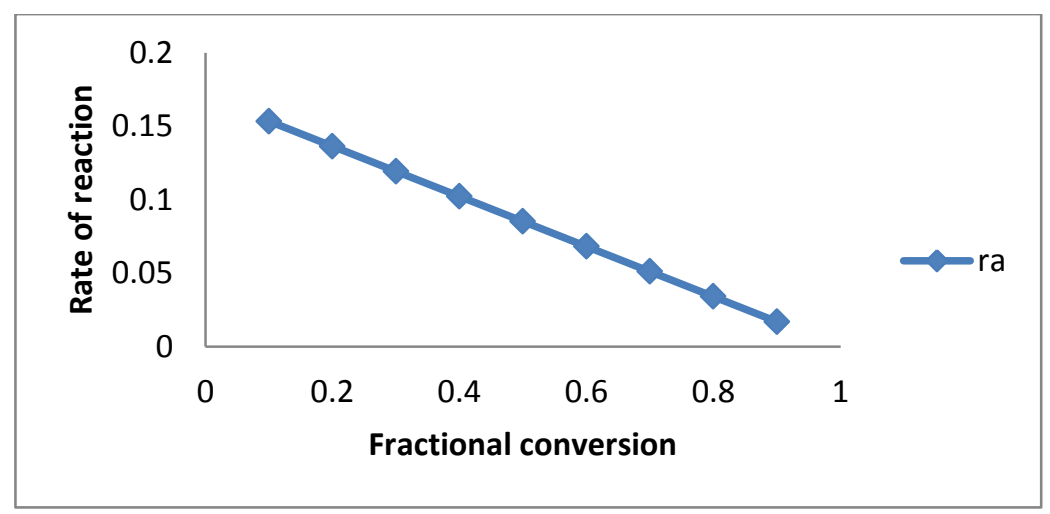

Figure 4: Rate of reaction against fractional conversion

Figure 4 shows the rate of reaction with fractional conversion. The rate of reaction is inversely proportional to the fractional conversion. This means that at higher fractional conversion, the rate of reaction is very small and high volume of methane gas.

\subsection{Effect of Fractional Conversion on Volume of Reactors}

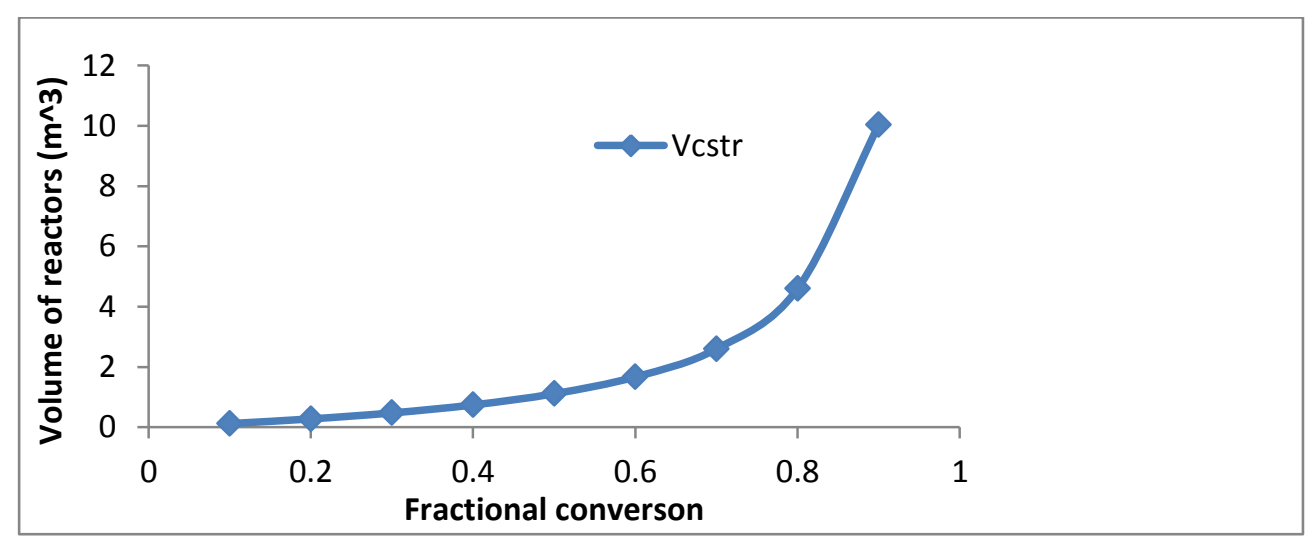

Figure 5: Volume of reactors (CSTR) versus Fractional conversion

Figure 5 depicts the volume of reactors continuous stirred tank reactor varying with fractional conversion. Comparatively, the volume of CSTR is high at $\mathrm{X}_{\mathrm{A}}=0.9$. Generally, the volume of the reactors increases exponentially as fractional conversion increases.

\subsection{Effect of Fractional Conversion on Diameter of Reactors}

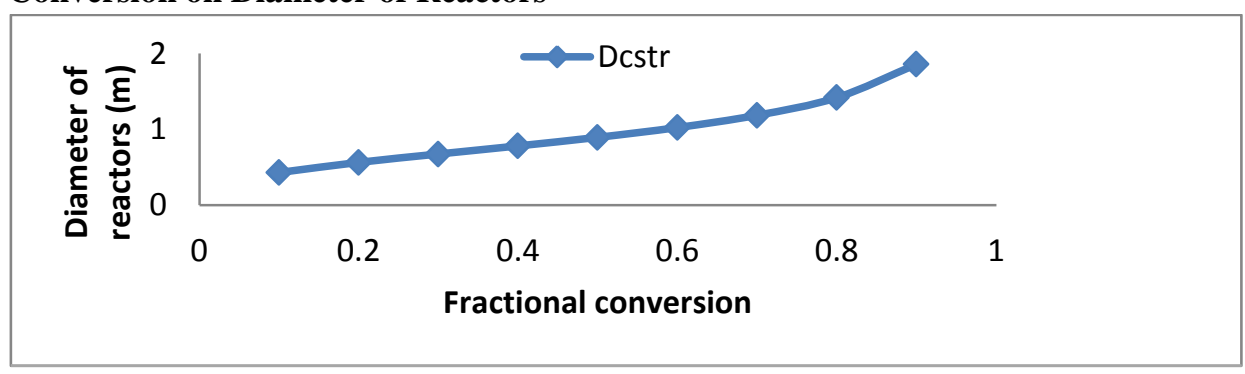

Figure 6: Diameter of reactors against Fractional conversion

Figure 6 shows the diameter of the reactor varying with fractional conversion. The diameter of the reactors (CSTR) generally increases as fractional conversion. 


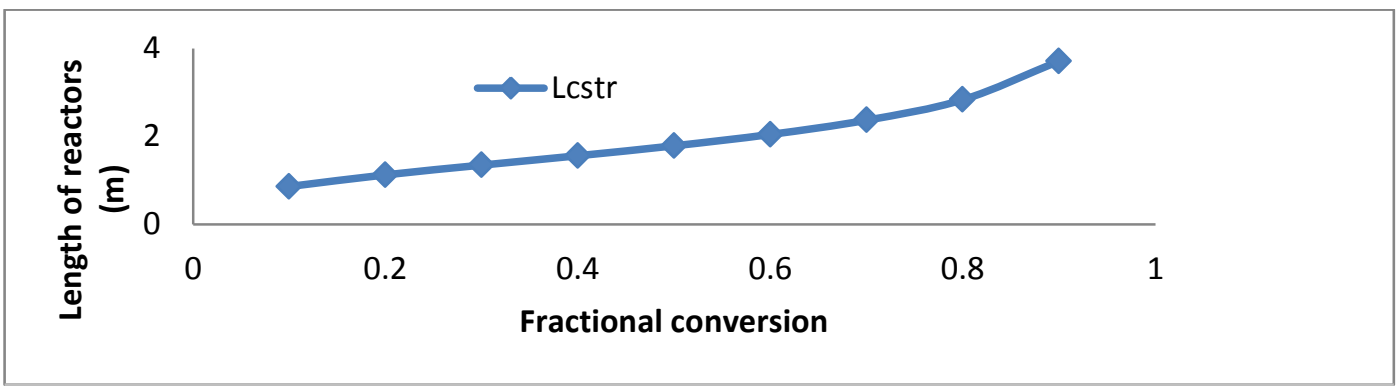

Figure 7: Length of reactors against Fractional conversion

Figure 7 depicts the length of the reactors varying with fractional conversion. The length increases as fractional conversion reaches maximum value of $\mathrm{L}_{\mathrm{CSTR}}=3.71 \mathrm{~m}$

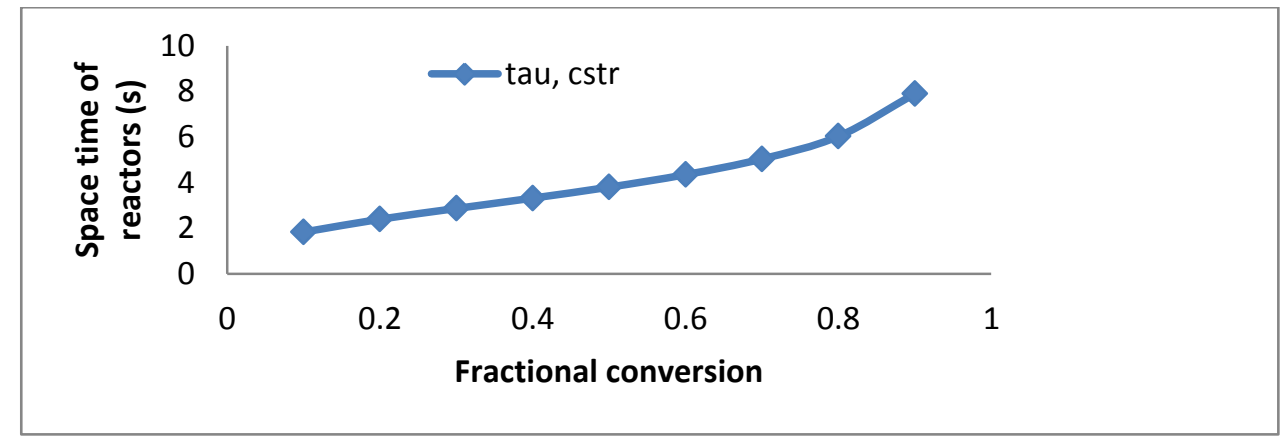

Figure 8: Space time of reactors against Fractional conversion

Figure 8 shows the variation of space time of reactors with fractional conversion. From the graph, the space time increases as fractional conversion increases . For instance, at $\mathrm{X}_{\mathrm{A}}=0.9, \tau_{\mathrm{PFR}}=5.46 \mathrm{secs}$.

\subsection{Effect of Fractional Conversion on Space Velocity of Reactors}

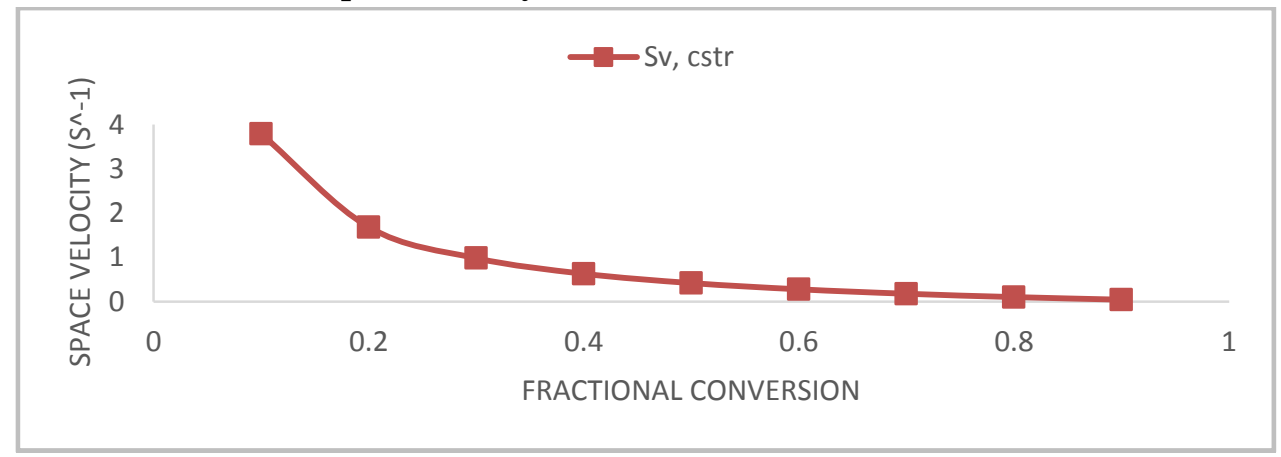

Figure 9: Space velocity of reactors against Fractional conversion

Figure 9 depicts the variation of space velocity of continuous stirred co-digester with fractional conversion. At same condition, the space velocity of reactors varies inversely to fractional conversion. At $\mathrm{X}_{\mathrm{A}}=0.9, \mathrm{~S}_{\mathrm{VCSTR}}=0.055^{-1}$ 


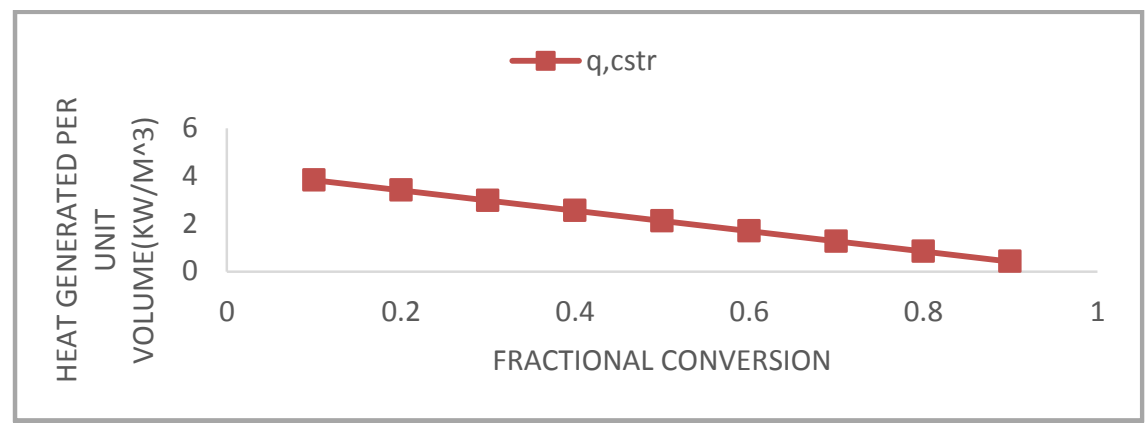

FIGURE 10: Heat generated per unit volume against Fractional conversion

FIGURE 10 shows the variation of heat generated per unit volume of reactors versus fractional conversion. Increase in fractional conversion results to decrease in heat generated per unit volume. $\mathrm{q}_{\mathrm{CSTR}}$ is far less than $\mathrm{q}_{\mathrm{PFR}}$ due to high volume produced from CSTR than PFR. At $\mathrm{X}_{\mathrm{A}}=0.9, \mathrm{q}_{\mathrm{CSTR}}=0.426 \mathrm{kw} / \mathrm{m}^{3}$ and $\mathrm{q}_{\mathrm{PFR}}=1.67 \mathrm{kw} / \mathrm{m}^{3}$. Very small heat is generated per unit for CSTR.

\subsection{CONCLUSION AND RECOMMENDATIONS}

\subsection{Conclusion}

Hypothetical design equations for the modeling of Isothermal Continuous Stirred Co-digester unit is developed using cowdung and grass clippings as source of raw materials. The developed models were capable of computing digester volume, length, space time space velocity, heat generation per unit volume and other associated engineering dimensions as a function of fractional conversion and parametric product design basics.

The results obtained were quit comparable and in-line with design expectations as volume, length and space time increases with increase in fractional conversion. While space velocity and heat generation per unit volume increase with decrease in fractional conversion.

\subsection{Recommendations}

This project was limited to the development of hypothetical design models for Continuous Stirred flow cow-dung and grass clippings Co-digester unit for biogas production at Isothermal condition using Gompertz kinetic model. Therefore, authors I recommend that further work should be carried out on the following;

- Cow-dung and grass clippings co-digester units should be developed for the simulation of the functional design dimensions using Gompertz kinetic model at non-isothermal condition of continuous and plug flow co-digester units at steady state.

- Isothermal condition of plug flow co-digester for cow-dung and grass clippings

- Cow-dung and grass clippings co-digester heat exchanger units should be developed for the simulation of the functional design dimensions using Gompertz kinetic model at both Isothermal and Non-isothermal condition.

- Evaluate the performance criteria for all co-digester types in other to ascertain the optimal product routes.

\section{REFERENCES}

1. Abdulsalam, S. \& Yusuf, M. (2015). A Kinetic Study of Biogas Produced from Cow and Elephant Dungs using Residual Substrate Concentration Approach. Chemical Engineering and Science, 3(1), 7 - 11.

2. Abowei M.F.N \& Goodhead T.O "Modeling of Isothermal CSTR Adsorption Tower for Sulphur Trioxide Hydration Using Vanadium Catalyst” Int'l Journal of Modern Engineering Science, 2014, 3(1): 39-60 (ISSN:2167-1133).

3. Ali kasap, Ramazam Aktas, Emre Dulger.(2012). Journal of Agricultural Machinery Science, 8(3), 271-277.

4. Allan, H. (1998). Grass Productivity. Island Press Conservation Classics Series, Washington DC.

5. Angelidaki, I. (1996). The Biogas Process: Energy from Biomass (6362).

6. Angelidaki I, Ellegard L, \& Ahring B.K. (2003). Application of the anaerobic digestion process. Adv Biochem Eng Biotechnol. (82), 1-33

7. Anthony, N.M., Mohammed, B., Tumisang, S. and Catherine, J. (2015). The Kinetic of Biogas Rate from Cow-Dung and Grass Clippings.

8. Igoni, A.H. \& Harry, I.S.K. (2017). Design Models for Anaerobic Batch Digesters Producing Biogas from Municipal Solid Waste. InternationalJournal of Biogas, 19(2), $11-19$. 
9. Etuwe, C.N., Momoh, Y.O.L. \& Iyagba, E.T. (2016). Development of Mathematical Models and Application of the Modified Gompertz Model for Designing Batch Biogas Reactors. Springer Science and Business Media Dordrecht, 315 326.

10. Igoni A.H., Abowei M.F.N., Ayotamuno M.J., \& Eze C.L. (2008). Effect of Total Solids Concentration of Municipal Solid Waste on the Biogas produced in an Anaerobic Continuous Digester. Agricultural Engineering International: the CIGR Ejournal, X:7-10.

11. John, B.B. (2007). Reactor design and reactor kinetics engineering. $5^{\text {th }}$ edition, Butter-worth-Heinemann.

12. Lastella, G., Testa, C., Cornacchia, G., Notomicola, M., Voltasio, F. \& Sharma, V.K. (2002). Anaerobic Digestion of Semi Solid Organic Waste Biogas Production and its Purification pdf. Energy Conservation and Management, 43.

13. Latinwo, G.K. \& Agarry, S.E. (2015). Modelling the kinetics of Biogas Production from Mesophilic Anaerobic CoDigestion of Cow Dung with Plantain Peels. International Journal of Renewable Energy Development, 4(1), 55 - 63.

14. Matheri, A.N. (2015). Analysis of the Biogas Productivity from Dry Fermentation of Organic Fraction of Municipal Solid Waste.

15. Matheri, A.N., Belaid, M., Seodigeng, T. \& Ngila J.C. (2016). The Role of Trace Elements on Anaerobic Co-digestion in Biogas Production. In Proceedings of the World Congress on Engineering, London, U.K.

16. Matheri, A.N., Belaid, M., Seodigeng, T. \& Ngila, C.J. (2015). The Kinetic of Biogas Rate from Cow Dung and Grass Clippings. International Conference on Latest Trends in Engineering and Technology, 26 - 27.

17. Matheri, A.N., Ndiweni, S.N., Belaid, M., Muzenda, E. \& Hubert, R. (2017). Optimizing Biogas Production from Anaerobic Co-digestion of chicken Manure and Organic Fraction of Municipal Solid Waste. Renewal and Sustainable Energy Review, 80, $756-764$.

18. Monnet, F. (2003). An Introduction to Anaerobic Digestion of Organic Waste, Industrial to anaerobic digestion November 2003. Pdf (27 $7^{\text {th }}$ November, 2017).

19. Omer, T.O. \& Fedalla, M.O. (2002). Engineering Design and Economic Evaluation of a Family-Sized Biogas Project in Nigeria. Technovation, $12-15$.

20. Ostream, K. (2004). Green Waste; Anaerobic Digestion for Treating the Organic Fraction of Municipal Solid Wastes. Unpublished M.Sc Thesis in Earth Resources Engineering Department of Earth and Environmental Engineering Foundation of School of Engineering and Applied Science, Columbia University.

21. Perry, H.R. \& Green, W.D. (2008). Perry’s Chemical Engineering Handbook. $8^{\text {th }}$ Edition. New York: McGraw-Hill Publishers, 731-738.

22. Perry, H.R. \& Green, W.D. (2008). Perry's Chemical Engineering Handbook. $8^{\text {th }}$ Edition. New York: McGraw-Hill Publishers, 831-845.

23. Pesta, G. (2007). Anaerobic Digestion of Organic Residues and Wastes. In: Oreopoulou V., Russ, W. Editors. Utilization of By-products and Treatment of Waste in the Food Industry. New York: Spinger, $53-73$.

24. Sinnot, R. \& Towler, G. (2009). Chemical engineering design. $5^{\text {th }}$ edition. Butter-worth-Heinemann.

25. Sreekrishnan, T.R., Kohli, S. \& Rana, V. (2004). Enhancement of Biogas Production from Solid Substrates using Different Techniques - a Review. Bioresource Technology, 95(1) 1 - 10.

26. Themelis, N.J. and Verma, S. (2004). The Better Option: Anaerobic Digestion of Organic Waste in MSW. Waste Management World January/February 2004. (27th November, 2018).

\section{MENCLATURE}

\section{Symbol Definition}

$\mathrm{M}_{\mathrm{A}}$

$\mathrm{M}_{\mathrm{B}}$

$\mathrm{M}_{\mathrm{C}}$

$\mathrm{G}_{\mathrm{A}}$

$\mathrm{G}_{\mathrm{B}}$

$\mathrm{G}_{\mathrm{C}}$

$\nabla_{\mathrm{A}}$
Molecular Weight of Glucose

Molecular Weight of Carbondioxide

Molecular Weight of Methane

Mass Flow Rate of Glucose

Mass Flow Rate of Carbondioxide

Mass Flow Rate of Methane

Specific Density of Glucose

Specific Density of Carbondioxide

Specific Density of Methane

Volumetric Flow Rate of Glucose

Volumetric Flow Rate of Carbondioxide

Volumetric Flow Rate of Methane

Initial Concentration of Reactant

Initial Pressure

Initial Temperature of Feed

Gas Constant

Initial Flow Rate of Glucose

Cumulative of Specific Biogas Production
Total Volumetric Flow Rate of Reactants

Unit
$\mathrm{Kg} / \mathrm{mol}$
$\mathrm{Kg} / \mathrm{mol}$
$\mathrm{Kg} / \mathrm{mol}$
$\mathrm{Kg} / \mathrm{s}$
$\mathrm{Kg} / \mathrm{s}$
$\mathrm{Kg} / \mathrm{s}$
$\mathrm{m}^{3} / \mathrm{kg}$
$\mathrm{m}^{3} / \mathrm{kg}$
$\mathrm{m}^{3} / \mathrm{kg}$
$\mathrm{m}^{3} / \mathrm{s}$
$\mathrm{m}^{3} / \mathrm{s}$
$\mathrm{m}^{3} / \mathrm{s}$
$\mathrm{m}^{3} / \mathrm{s}$
$\mathrm{mol} / \mathrm{m}^{3}$
$\mathrm{~N} / \mathrm{m}^{2}$
${ }^{0} \mathrm{~K}$
$\mathrm{Nmmol}{ }^{-1} \mathrm{k}^{-1}$
$\mathrm{~mol} / \mathrm{s}$
$\mathrm{mL}$


International Journal of Advances in Scientific Research and Engineering (ijasre), Vol 5 (3), March-2019

\begin{tabular}{|c|c|c|}
\hline A & Biogas Production Potential & $\mathrm{mL}$ \\
\hline$\mu$ & Maximum Biogas Production Rate & day \\
\hline$\lambda$ & Lag Phase Period & day \\
\hline $\mathrm{T}$ & Cumulative Time for Biogas Production & day \\
\hline $\mathrm{E}$ & Mathematical Constant & - \\
\hline$P_{i}$ & Design Pressure & $\mathrm{N} / \mathrm{mm}^{2}$ \\
\hline $\mathrm{D}_{\mathrm{i}}$ & Design Diameter & $\mathrm{mm}$ \\
\hline$J$ & Weld Type (Fully Radiographed) & - \\
\hline$f$ & Design Stress & $\mathrm{N} / \mathrm{mm}^{2}$ \\
\hline $\mathrm{C}_{\mathrm{P}}$ & Full Face Gasket & - \\
\hline $\mathrm{T}_{\mathrm{O}}$ & Operating Temperature & ${ }^{\mathrm{O}} \mathrm{C}$ \\
\hline $\mathrm{X}_{\mathrm{A}}$ & Fractional Conversion & - \\
\hline $\mathrm{L}_{\mathrm{st}}$ & Stirrer Length & $\mathrm{m}$ \\
\hline $\mathrm{L}_{\mathrm{R}}$ & Reactor length & $\mathrm{m}$ \\
\hline $\mathrm{C}$ & Allowance & $\mathrm{m}$ \\
\hline$V_{\text {PFR }}$ & Volume of Plug Flow Reactor & $\mathrm{m}^{3}$ \\
\hline $\mathrm{V}_{\mathrm{CSTR}}$ & Volume of Continuous Stirred Tank Reactor & $\mathrm{m}^{3}$ \\
\hline$t$ & Space Time & $\mathrm{S}$ \\
\hline $\mathrm{S}_{\mathrm{V}}$ & Space Velocity & $\mathrm{S}^{-1}$ \\
\hline Q & Quantity of Heat & $\mathrm{j} / \mathrm{s}$ \\
\hline Q & Quantity of Heat Per Unit Volume of Reactor & $\mathrm{Kw} / \mathrm{m}^{3}$ \\
\hline$\Delta_{P}$ & Pressure Drop & Kра \\
\hline $\mathrm{Y}(\mathrm{t})$ & Rate Constant & $\mathrm{ml}$ \\
\hline
\end{tabular}

